Davor Radić, spec. iur. ${ }^{1}$

Ana Radić, mag. iur. ${ }^{2}$

\title{
ARBITRAŽNI SUD HRVATSKOG NOGOMETNOG SAVEZA S POSEBNIM OSVRTOM NA PRAVILNIK O RADU ARBITRAŽNOG SUDA HNS-A
}

UDK: $349: 796$

DOI: $10.31141 /$ zrpfs.2019.56.134.985

Izvorni znanstveni rad

Primljeno: 1. VIII. 2019.

\begin{abstract}
U zadnjih dvadesetak godina nogomet kao sport evoluirao je ne samo na terenu već i "izvan terena". Bezbroj je primjera toga no jedan od najznačajnijih primjera u Republici Hrvatskoj zasigurno su nogometni arbitražni sporovi i njihovo rješavanje. Nogometni sporovi u pogledu statusnih pitanja igrača, klubova, trenera, kao i onih pitanja u svezi s naknadom za treniranje i razvoj igrača te naknadom na ime mehanizma solidarnosti između klubova i drugih udruga koji pripadaju Hrvatskom nogometnom savezu te vezano uz to i imovinskih sporova koji nastaju između pojedinih subjekata HNS-a (klub-klub, igrač-klub, trener-klub, klub-županijski nogometni savez) rješavaju se pred Arbitražnim sudom HNS-a. Koautori ovim radom objašnjavaju način vođenja i rješavanja sporova pred Arbitražnim sudom HNS-a, kao i organizacijske i postupovne odredbe Pravilnika o radu Arbitražnog suda HNS-a.
\end{abstract}

Ključne riječi: arbitraža, spor, nogomet, sportsko pravo, ugovor

\section{UVOD}

Ponajprije možemo reći da je arbitraža (izabrano suđenje) alternativni način rješavanja sporova pred trećim, nezavisnim i nepristranim tijelom (arbitražni sud) čija se nadležnost izvodi iz volje stranaka i koje je ovlašteno donijeti za stranke obvezujuću odluku.

Arbitraža je način rješavanja sporova u kojem treća nepristrana osoba od povjerenja stranaka (arbitar) ima ovlast odlučiti o sporu svojom odlukom. ${ }^{3}$ Arbitraža danas nije novost - ona se ubraja među etablirane načine rješavanja sporova, a posvećeno joj je niz djela i rasprava. Osobito u području rješavanja međunarodnih

1 Davor Radić, vanjski suradnik na Pravnom fakultetu Sveučilišta u Splitu - Poslijediplomski specijalistički studij Športsko pravo, član Hrvatskog društva za športsko pravo, odvjetnik u OD Radić \& Radić, Split.

2 Ana Radić, odvjetnica u OD Radić \& Radić, Split.

3 Vidi Čavlina, Andreja, "Rješavanje sporova arbitražom u praksi pred Stalnim izabranim sudištem Hrvatske gospodarske komore", Hrvatska gospodarska komora - Sektor za trgovinu, Sedamnaesti forum poslovanja nekretninama, 2012., str. 1. 
trgovačkih sporova, ali i drugdje, arbitražne klauzule u ugovorima postale su njen sastavni dio. Zato se ponekad smatra da arbitražu ne treba svrstavati u alternativne načine rješavanja sporova, već u standardne, potvrđene metode, posebno u pojedinim područjima i za pojedine vrste predmeta. ${ }^{4}$

Arbitražno sudovanje razvilo se kao odraz nezadovoljstva zbog učmalog, sporog, skupog, krutog i nesigurnog državnog sudovanja. Na međunarodnom planu afirmira se kao odraz nepovjerenja prema pravosudnim organima i zakonodavstvu države protivnika. Sporazum o arbitraži predstavlja kompromisnu točku do koje partneri dolaze jedan drugome u susret, odričući se domaćeg pravosuđa i osjećaja sigurnosti koji im ulijeva svojim postupanjem i pravilima na temelju kojih odlučuje. Porast prakse arbitražnog sudovanja tumači se i kao simptom loših prilika u državnom pravosuđu. Intenzitet rada izbranih sudova u funkcionalnoj je ovisnosti o kvaliteti rada državnih sudova. Ukoliko su državni sudovi pouzdaniji, efikasniji i ekonomičniji, utoliko stranke imaju manje razloga da od njih "bježe" odlučujući se da spor povjere arbitražnom sudu. ${ }^{5}$

Dakle, svaki arbitražni postupak, pa tako i postupak pred Arbitražnim sudom HNS-a, temelji se na volji stranaka a ne na ovlasti države. Dakle, arbitražno suđenje pretpostavlja derogiranje ovlaštenja, odnosno nadležnosti državnog sudstva. U tom smislu arbitraža jest i aktivnost provođenja suđenja u sporu pred arbitražnim sudom. Postupak pred arbitražnim sudom jest suđenje, čak i onda kada se po ovlaštenju stranaka sudilo po načelu pravičnosti. ${ }^{6}$

Trivina klasična definicija arbitraže, objavljena i u posljednjem izdanju Građanskog parničnog procesnog prava iz 1986., glasila je: "Izbrani sud ili arbitraža (arbitrage, arbitra to, arbitration, arbitraž), je samoupravno, nedržavno tijelo, sastavljeno od jedne ili višse osoba o čijem su se izboru stranke sporazumjele, kome stranke sporazumno i dobrovoljno povjeravaju donošenje meritorne odluke u sporu, a zakon tu odluku iznednačuje s pravomoćnom sudskom presudom".?

Iz Trivine definicije izbranog suda sudac Visokog trgovačkog suda RH Krešimir Musa izveo je pet kriterija na temelju kojih bi se moglo utvrditi koji bi se izbrani sud moglo smatrati "pravim izbranim sudom", 8 te je to poslije ponovio i u svojim

4 Pogledaj Triva, Siniša, Uzelac, Alan, Komentar Zakona o arbitraži i drugi izvori hrvatskog arbitražnog prava, Narodne novine, Zagreb, 2007., str. XL

5 Tako Čalija, Branko, Omanović, Sanjin, Građansko procesno pravo, Univerzitet u Sarajevu, Pravni fakultet, Sarajevo, 2000., str. 92.

6 Detaljnije Triva, Siniša, "Arbitražno ili državno sudovanje", Pravo u gospodarstvu, god. 43., 2004., br. 2, str. 10 .

7 Podrobnije Triva, Siniša, Belajec, Velimir, Dika, Mihajlo, Građansko parnično procesno pravo, 6. izmijenjeno i dopunjeno izd. Zagreb, Narodne novine, 1986., Udžbenici Sveučilišta u Zagrebu, str. 687. te Musa, Krešimir, Arbitraža u organizaciji udruženog rada - samoupravni sud, Zagreb, 1982., str. 16-17.

8 Više Musa, Krešimir, "Reševanje sporov iz poslovnih razmerij pred arbitražo (razsodiščem) pri gospodarski zbornici", Združeno delo, 6/80; Musa, Krešimir, "Rješavanje sporova iz poslovnih odnosa pred arbitražom (izbranim sudom) pri privrednoj komori", Naša zakonitost, 7-8/81. 
drugim radovima. ${ }^{9}$ Kao radna definicija može se prihvatiti ona po kojoj je arbitraža neovisno, nedržavno tijelo kojem stranke sporazumno povjeravaju donošenje odluke kojom se rješava njihov imovinskopravni spor. ${ }^{10}$

Arbitraža ima nedvojbeno svoje prednosti u odnosu na državne sudove, a te prednosti su, prije svega, u mogućnosti izbora stručnih osoba koje će voditi arbitražu, u bržem provođenju postupka, mogućnosti sporazuma o mjerodavnom pravu te $u$ povjerljivosti postupka i dokumentacije koja se koristi u postupku. ${ }^{11}$ No naravno, to samim tim ne znači da se odluke arbitražnih sudova ne mogu poništavati, a sve kako je to predviđeno odredbama Zakona o arbitraži jer je takva mogućnost tim zakonom predviđena podnošenjem tužbe za poništaj arbitražnog pravorijeka.

Sportske arbitraže često imaju i obilježja tzv. prisilnih arbitraža (arbitrage obligatore, compulspry arbitration, Zwangsshiedsgericht), kojima se stranke moraju obratiti radi rješavanja određenih sporova. ${ }^{12}$

Ovdje možemo skrenuti pozornost na članak 59. Statuta krovne nogometne organizacije FIFA-e koja je tom odredbom propisala da je zabranjeno obraćanje redovnim sudovima, osim ukoliko to nije posebno utvrđeno pravilnicima FIFA-e, a u tom smislu nogometni savezi moraju u svoje statute i pravilnike uključiti odredbu prema kojoj se zahtjevi u svezi sa sporovima ne mogu podnositi redovnim sudovima, nego je potrebno ugraditi odredbu o arbitraži. Takvi sporovi pokreću se pred neovisnim i pravilno sastavljenim arbitražnim sudom priznatim u skladu s odredbama saveza ili konfederacije, ili TAS/CAS. Nacionalni nogometni savezi također osiguravaju provedbu ove odredbe u savezu, ako je potrebno uvođenjem takve obveze za svoje članove. Savezi izriču kazne svakoj strani koja propusti poštovati ovu obvezu i osigurati da se svaka žalba protiv takvih kazni jednako tako striktno dostavlja arbitraži, a ne redovnim sudovima.

Dakle, imajući u vidu činjenicu da UEFA (Europska nogometna federacija) te FIFA (Svjetska nogometna organizacija) svojim nacionalnim članicama (savezima) vrlo često nameću svoja vlastita "pravila igre" i to baš s obzirom na ugovaranje tzv. arbitražne klauzule za rješavanje nogometnih sporova, to i Hrvatskom nogometnom savezu nije preostalo ništa drugo nego da u svoje akte implementira te prisilne odnosno obligatorne odredbe vođenja nogometnih sporova isključivši pri tom nadležnost redovnih sudova.

U Republici Hrvatskoj nogometni sporovi u pogledu statusnih pitanja i u vezi s tim imovinskih sporova koji nastaju između pojedinih subjekata HNS-a rješavaju se pred Arbitražnim sudom Hrvatskog nogometnog saveza (u daljnjem tekstu: Arbitražni sud HNS-a). Upravo zbog toga možemo reći da postupak

9 Podrobnije vidi Musa, Krešimir, Arbitraža v organizaciji združenog dela Ljubljana, 1981., str. 26-28; op. cit. str. 16-18 u bilješci 3; Musa, Krešimir, Arbitraža vo organizacija na združenot trud samotupraven sud, Skopje, 1986., str: 31-33; op. cit. str. 307-309. u bilješci 5.

10 Gorenc, Vilim, Rječnik trgovačkog prava, Masmedia, Zagreb 1997., str. 22.

11 Usporedi Jug, Jadranko, "Načini okončanja arbitražnog postupka - dileme i prijedlozi", Pravo u gospodarstvu, 2006., str. 1.

12 Tako Musa, Krešimir, op. cit. str. 35. 
pred Arbitražnim sudom HNS-a predstavlja domaću sportsku arbitražu jer je njezino mjesto na području Republike Hrvatske, što znači da se na tu arbitražu, osim Pravilnika o radu Arbitražnog suda HNS-a, primjenjuje i Zakon o arbitraži Republike Hrvatske (u daljnjem tekstu: Zakon o arbitraži ili ZA). ${ }^{13}$ Dakle, uređenje arbitražnog postupka utvrđuje Zakon o arbitraži koji se od donošenja do danas nije mijenjao, i doista se može smatrati suvremenim aktom jer je u vrijeme donošenja prihvatio zapadnoeuropske uzore i omogućio izrazito veliku slobodu u ugovaranju arbitraže za sve stranke.

Danas se većina sportskih sporova rješava pred arbitražnim sudovima. Sve prednosti arbitražnog sudovanja odavno su prepoznate u sportu, pa je danas rijetkost da se spor vezan uz određeni sport nađe pred državnim sudom. Tome je, među ostalim, razlog i određena bojazan sportskih organizacija i sportaša da ponašanje koje je sastavni dio određenog sporta može pred državnim sudom biti ocijenjeno i proglašeno protupravnim (primjerice, kod nekih borilačkih sportova). ${ }^{14}$ Naravno, to ne znači da ne postoje i drugi nogometni sporovi koji se vode pred redovnim sudovima no velika većina tzv. nogometnih sporova u Republici Hrvatskoj vodi se upravo pred Arbitražnim sudom HNS-a i upravo zbog toga to će ovim radom analizirati rad Arbitražnog suda HNS-a te organizacijske i postupovne odredbe Pravilnika o radu Arbitražnog suda HNS-a.

\section{POVIJESNI RAZVOJ ARBITRAŽNOG SUDA HNS-A}

Sama institucija suvremene arbitraže formirala se nakon Francuske revolucije, no u početku nije bila najbolje prihvaćena zbog negativno nastrojenog stava državnih sudova koji su predstavljali konkurenciju. ${ }^{15}$ Tako se u buržoaskom pravnom poretku arbitražno sudovanje manifestira kao odraz dominirajućeg shvaćanja o dispozitivnom karakteru građanskog prava. Ako mogu svojim ugovorom određivati sadržaj građanskopravnih odnosa, strankama treba priznati pravo da i sporove iz takvih odnosa reguliraju svojim dispozicijama, pa i tako da spor oduzmu iz kompetencije državnog pravosuđa i da ga iznesu pred osobe svog povjerenja. ${ }^{16}$

Arbitraža u Hrvatskoj ima dugačku tradiciju. U zagrebačkim povijesnim analima možemo naći podatke da su se sporovi malih trgovaca i obrtnika krajem 19. i početkom 20. stoljeća u pravilu rješavali arbitražom. ${ }^{17}$ Nakon 1965. godine, mogućnost rješavanja sporova u Hrvatskoj arbitražom se proširuje i na domaće

13 Detaljnije Zakon o arbitraži (Narodne novine, broj 88/01).

14 Tako tvrdi Puljko, Vjekoslav, "Arbitražno rješavanje sporova u nogometu", Pravni fakultet u Osijeku, Časopis za pravne i društvene humanističke znanosti Pravni vjesnik, broj 10/2., 2010., str. 58.

15 Više o tome Giunio, Miljenko, "Arbitraža i državni sud", Stručne informacije br. 1/1995, Zagreb, str. 13.

16 Kasagić, Rajko, Međunarodno poslovno pravo, Univerzitet u Banjoj Luci, Ekonomski fakultet, Banja Luka, 2008., str. 421.

17 Vidi Uzelac, Alan, "Pet godina međunarodne trgovačke arbitraže u Hrvatskoj", Pravo u gospodarstvu , 1998., vol. 37., str. 131. 
trgovačke odnose. ${ }^{18}$ Krajem rujna 2001., kao kulminacija razvoja i usklađivanja arbitraže u RH s međunarodnim standardima, donosi se već spomenuti Zakon o arbitraži što postaje prvi zakon koji u potpunosti obuhvaća i normira arbitražnu materiju u nas. ${ }^{19}$

Arbitražni sud Hrvatskog nogometnog saveza osnovan je odlukom Izvršnog odbora Hrvatskog nogometnog saveza još 2002. godine. Pokretač i idejni začetnik osnivanja Arbitražnog suda HNS-a bio je Stanko Hautz, tadašnji sudac Vrhovnog suda RH te dugogodišnji predsjednik Arbitražnog suda HNS-a za kojeg možemo reći da je u to vrijeme bio vizionar ispred svoga vremena, a njegov rad na isti takav način vrlo uspješno je nastavio Ivica Veselić, sudac Županijskog suda u Zagrebu, koji je sadašnji predsjednik Arbitražnog suda HNS-a.

Naime, s obzirom na činjenicu da je Svjetska nogometna organizacija (u daljnjem tekstu: FIFA) svojim internim aktima predvidjela mogućnost nacionalnim nogometnim savezima za osnivanje neovisnog i nepristranog arbitražnog suda, to je na prijedlog g. Hautza tadašnji Izvršni odbor HNS-a prihvatio tu ideju te unutar HNS-a i osnovao arbitražni sud - Arbitražni sud HNS-a. Tako je Izvršni odbor HNS-a, sukladno članku 17. Pravilnika o statusu igrača (Službeni Glasnik br. 35/02.), na svojoj sjednici održanoj 20. kolovoza 2002. godine donio Poslovnik o radu Arbitražnog suda HNS-a. ${ }^{20}$ Nakon toga, Izvršni odbor HNS-a je temeljem članka 42. Statuta HNS-a (Glasnik 32/12, 22/13) na svojoj sjednici održanoj 11. listopada 2013. godine donio, a na sjednicama održanima 26. studenoga 2015., 22. veljače 2017., 29. siječnja 2018. i 4. lipnja 2018. izmijenio i dopunio Pravilnik o radu Arbitražnog suda HNS-a koji je i danas na snazi.

Razlog donošenja gore citiranog Pravilnika o radu Arbitražnog suda HNS-a leži u činjenici što određene odredbe Poslovnika o radu Arbitražnog suda HNS-a nisu bile u skladu sa Zakonom o arbitraži, što je naposljetku doprinijelo velikom broju poništenih odluka Arbitražnog suda HNS-a u postupcima pred Županijskim sudom u Zagrebu te Vrhovnim sudom RH u Zagrebu, odluka koje ćemo detaljno analizirati o ovom radu.

Za rad i ustroj Arbitražnog suda HNS-a svakako je značajan Zakon o arbitraži. Zakon o arbitraži opći je arbitražni zakon koji sadrži pravila za sve vrste arbitraža, bez obzira na pravno područje u kojem se arbitraža provodi i bez obzira na vrstu arbitraže, ne samo u onim sporovima u kojima je dispozitivnost u uređivanju

18 Podrobnije Uzelac, Alan, International Commercial Arbitration in Croatia 1991-1998 - A Log of the Activities of the Permanent Arbitration Court at the Croatian Chamber of Commerce, Croat. Arbit. Yerab., vol. 5, 1998., str. 112.

19 Bosiljevac, Vladimir, Analiza rada Stalnog izabranog sudišta pri Hrvatskoj gospodarskoj komori, Pravni fakultet u Zagrebu, 2002., Seminarski rad, str.7.

20 Vidi odluku Izvršnog odbora Hrvatskog nogometnog saveza od 20. kolovoza 2002. godine. Napominjemo da je Izvršni odbor Hrvatskog nogometnog saveza ovaj Poslovnik o radu Arbitražnog suda HNS-a na svojim sjednicama održanima dana 19. XII. 2008., 6. VIII. 2011., 8. VIII. 2013., 26. XI. 2015., 22. II. 2017., 29. I. 2018. i 4. VI. 2018. dopunio i izmijenio. 
stranačkih odnosa potpuna, nego i u onima u kojima je dispozitivnost ograničena. Polje primjene Zakona o arbitraži odnosi se i na tzv. prisilne ili neprave arbitraže. ${ }^{21}$

Povijesno gledano, možemo reći da je temeljna novina ovog novog hrvatskog Zakona o arbitraži, koji je Sabor Republike Hrvatske donio 28. rujna 2001. godine, odstupanje od do tada važećih pravila, slijedeći međunarodno značajne uzore naročito Njujoršku konvenciju o priznanju i ovrsi stranih arbitražnih pravorijeka od 10. lipnja 1958. godine te UNCITRAL, Model zakona o međunarodnoj trgovačkoj arbitraži od 11. prosinca 1985. godine. ${ }^{22} \mathrm{Uz}$ razloge sistemske naravi, željelo se ostvariti i pojedine praktične ciljeve, stvaranjem normativne podloge za očekivana značajnija strana ulaganja, kojima se, kako se tvrdilo, nerealno nadati ako inozemne investiture na domaćem planu ne dočeka razrađeno i osuvremenjeno arbitražno pravo koje im može jamčiti da će njihovi interesi uživati pravnu zaštitu kakvu imaju u poretku čiji su pripadnici. ${ }^{23}$ Konačni prijedlog Zakona o arbitraži rezultat je rada Radne skupine Ministarstva pravosuđa, uprave i lokalne samouprave. ${ }^{24}$ Naime, tako je Zakon o arbitraži odredio minimum koji svaki arbitražni sud, pa tako i Arbitražni sud HNS-a, mora poštovati u svome postupanju u cilju ostvarenja ravnopravnosti stranaka tako da su stranke slobodne odrediti da će se kao procesna pravila primjenjivati upravo pravila tog suda, ili mogu ugovoriti primjenu nekog procesnog zakona, a čak je moguće arbitražni sud ovlastiti da vodi postupak na način kako to najbolje zna, ali bez ugroze prisilnih propisa koji imaju za cilj zaštitu navedene ravnopravnosti stranaka.

Arbitražni sud HNS-a predstavlja tzv. institucionalnu arbitražu jer je ta arbitraža organizirana i vođena po pravilima arbitražne ustanove (arbitražnog sudišta), što je uređeno Pravilnikom o radu Arbitražnog suda HNS-a.

\section{ARBITRAŽNI SUD HNS-A}

\section{Opseg primjene}

Pravilnikom o radu Arbitražnog suda Hrvatskog nogometnog saveza uređuju se nadležnost, sastav, sjedište, izbor članova suda i pravila postupka pred Arbitražnim sudom Hrvatskog nogometnog saveza, što će sve biti detaljno objašnjeno u nastavku ovog rada (članak 1. Pravilnika o radu Arbitražnog suda HNS-a).

21 Usporedi Triva, Siniša, Uzelac, Alan, op. cit. str. 4.

22 Vidi detaljnije Triva, Siniša, "Recepcija UNCITRAL-ovog Model zakona o međunarodnoj trgovačkoj arbitraži u hrvatsko arbitražno pravo", $P u G, 34 / 1-2: 1995$, str.1-24

23 Tako Triva, Siniša, "Arbitražno rješavanje međunarodnih sporova", u: Međunarodna trgovačka arbitraža u Hrvatskoj i Sloveniji, Zagreb 1993., 1. HAD, str. 1-28.

24 Članovi Radne skupine Ministarstva pravosuđa itd. bili su: P. Dević, M. Giunio, I. Grbin, Z. Hamarić, H. Momčinović, B. Rumenjak, H. Sikirić, S. Triva (predsjednik), A. Uzelac (potpredsjednik), A. Vičić. 


\section{Definicije}

Svojim odredbama Pravilnik o radu Arbitražnog suda HNS-a propisuje definicije tog Pravilnika, a sve radi što lakšeg objašnjenja pojedinih pojmova u Pravilniku.

Tako je člankom 2. Pravilnika o radu Arbitražnog suda HNS-a propisano:

a) arbitražni postupak je postupak pred Arbitražnim sudom;

b) tužba je podnesak kojim se traži ispunjenje neke obveze ili raskid ugovora;

c) tužitelj je stranka koja svojim zahtjevom pokreće arbitražni postupak;

d) tuženik je stranka od koje se zahtjevom traži ispunjenje obveze;

e) arbitar je član Arbitražnog suda koji kao predsjednik ili član vijeća sudjeluje u arbitražnom postupku;

f) članovi Arbitražnog suda su predsjednik, zamjenik predsjednika i arbitri Arbitražnog suda. ${ }^{25}$

\section{Nadležnost}

Arbitražni je sud HNS-a samostalni i stalni jednostupanjski sud, nadležan za rješavanje sukoba interesa i statusnih pitanja trenera i igrača i u vezi s tim imovinskih sporova koji nastaju između pojedinih subjekata Hrvatskog nogometnog saveza, za odlučivanje u sporovima koji nastaju između pojedinih članova HNS-a, igrača, trenera i drugih pripadnika nogometne organizacije u vezi s nogometnim sportom na području Republike Hrvatske, kao i za ocjenjivanje zakonitosti konačnih odluka o pravima, obvezama i odgovornostima iz odnosa koji se ostvaruju u HNS-u i nogometnom sportu u Republici Hrvatskoj, a sve kako to propisuje članak 3. Pravilnika o radu Arbitražnog suda HNS-a (članak 3. Pravilnika o radu Arbitražnog suda HNS-a).

Kada kažemo "jednostupanjski sud", to znači da se radi o postupku čija je odluka pravomoćna danom donošenja, što podrazumijeva nemogućnost podnošenja žalbe. Ovo sve posebno iz razloga što Hrvatski nogometni savez nije, sukladno odredbama Zakona o arbitraži, unutar svoje ustanove osnovao arbitražu višega stupnja sa čijom nadležnošću su se stranke sporazumjele, koja bi rješavala o žalbama protiv pravorijeka Arbitražnog suda HNS-a. ${ }^{26}$ Uostalom, dvostupnost suđenja nerazdvojni je element temeljnih prava čovjeka/građanina i kao takva uvedena je u ustavne odredbe modernih pravnih sustava. ${ }^{27}$

25 Napominjemo da sukladno ranije važećim Poslovnikom o radu Arbitražnog suda HNS-a (koji je bio na snazi do donošenja Pravilnika o radu Arbitražnog suda HNS-a) to isti nije sadržavao definicije ovih temeljnih pojmova već su se one izvodile iz smisla njihove upotrebe u odredbama Poslovnika o radu Arbitražnog suda HNS.

26 Mogućnost arbitraže drugog stupanja predviđena je člankom 31. Zakona o arbitraži.

27 Podrobnije kod Ude, Lojze, "Pobijanje arbitražne odluke", Privreda i pravo, vol. 33, 1994., br. 3-4, str. 246-247. te Kandare, Boris, Pobijanje arbitražne odluke, Pravni fakultet u Splitu, Split, 1992., str. 13. 
Arbitražni sud ne može odlučivati o sporovima koji nastaju ili proizlaze iz međusobnih odnosa subjekata u nogometnoj organizaciji povodom primjene Pravila nogometne igre i drugih diskrecijskih ovlaštenja koja proizlaze iz naravi nogometnog sporta, o sporovima u vezi s natjecanjem (sporovima koji proizlaze iz primjene Pravilnika o nogometnim natjecanjima), kao niti o odlukama Skupštine HNS-a, Žalbene izborne komisije i odlukama donesenima u postupku licenciranja klubova. Arbitražni sud ne može odlučivati o sporovima za čije rješavanje nisu korištena sva pravna sredstva unutar HNS-a.

\section{Primjenjivo pravo}

U ostvarivanju svoje nadležnosti Arbitražni sud primjenjuje Statut i pravilnike HNS-a, naročito one koji su usvojeni na osnovi statuta i pravilnika FIFA-e. U slučajevima u kojima HNS nije regulirao odnose u ovom području, analogno se primjenjuju statut i pravilnici FIFA-e.

U pitanjima koja nisu regulirana gore citiranim propisima HNS-a i FIFA-e, Arbitražni sud primjenjuje odredbe Zakona o obveznim odnosima, Zakona o arbitraži i druge zakonske i podzakonske propise Republike Hrvatske. Ako neka pitanja postupovne naravi nisu regulirana Pravilnikom o radu Arbitražnog suda HNS-a, tada Arbitražni sud primjenjuje odredbe Zakona o arbitraži i, supsidijarno, Zakona o parničnom postupku (članak 4. Pravilnika o radu Arbitražnog suda HNS-a).

\section{Sastav}

Arbitražni sud čine predsjednik, zamjenik predsjednika i arbitri, koji imaju četverogodišnji mandat s mogućnošću obnove. Predsjednika i zamjenika predsjednika Arbitražnog suda imenuje Izvršni odbor HNS-a, među arbitrima koje su predložili klubovi i predstavnici igrača.

Arbitre utvrđuje Izvršni odbor HNS-a:

a) tri do pet arbitara na prijedlog udruženja igrača koje priznaje FIFPRO ili, ukoliko takvo udruženje ne postoji, na prijedlog kapetana seniorskih momčadi klubova Prve HNL,

b) tri do pet arbitara na prijedlog klubova Prve HNL,

c) zajednička lista od pet arbitara na prijedlog predstavnika igrača iz točke a) ovog članka i klubova Prve HNL.

Članovi Arbitražnog suda HNS-a diplomirani su pravnici (članak 5. Pravilnika o radu Arbitražnog suda HNS-a). ${ }^{28}$ Mišljenja smo da bi se ovu odredbu članka 5. Pravilnika o radu Arbitražnog suda HNS-a moglo izmijeniti te omogućiti da

28 Odredba članka 5. Pravilnika o radu Arbitražnog suda HNS-a ograničava pravo kandidiranja osobama koje nisu diplomirani pravnici, a koje zasigurno mogu imati znanja i sposobnosti da budu arbitri pred Arbitražnim sudom HNS-a. 
se i druge osobe, a ne samo diplomirani pravnici, mogu kandidirati za arbitra Arbitražnog suda HNS-a. Jer kako je tom odredbom jasno propisano tko predlaže arbitre, onda je samim tim logično da se tim osobama može proširiti odabir arbitara i na one koji nisu diplomirani pravnici.

\section{Obveza povjerljivosti}

Članovi Arbitražnog suda, kao i ostale osobe koje sudjeluju u radu Arbitražnog suda, obvezani su na službenu povjerljivost o svim činjenicama koje im postanu poznate tijekom obavljanja svojih funkcija. Naročito cee se suzdržati od otkrivanja sadržaja spora (članak 6. Pravilnika o radu Arbitražnog suda HNS-a).

\section{Vijeće i arbitar pojedinac}

Člankom 7. Pravilnika o radu Arbitražnog suda HNS-a propisano je da Arbitražni sud HNS-a vodi postupak i donosi pravorijek u vijećima. Vijeće čine po jedan arbitar kojega odredi svaka stranka i predsjednik vijeća kojega izaberu arbitri određeni od stranaka. Ukoliko tuženik ne odredi arbitra u roku od osam dana od dana poziva da to učini, arbitra ce odrediti predsjednik Arbitražnog suda ili njegov zamjenik. Za predsjednika vijeća mogu se odrediti arbitri imenovani sa zajedničke liste iz članka 5. st. 3. toč. c) Pravilnika o radu Arbitražnog suda HNS-a. Sudac redovnog suda Republike Hrvatske može biti samo predsjednik vijeća.

Zadnjim izmjenama i dopunama Pravilnika o radu Arbitražnog suda HNS-a nadopunjen je članak 7. tako da su u njemu dodatno na vrlo detaljan način razrađene odredbe u pogledu odabira arbitara te biranja predsjednika vijeća. Tako je propisano i da će arbitar kojega je birao tužitelj (u daljnjem tekstu: arbitar tužitelja) u roku od tri dana od dana davanja pisane izjave predložiti arbitru kojega je birao tuženik (u daljnjem tekstu: arbitar tuženika) predsjednika vijeća. U roku od tri dana od dana primitka tog prijedloga iz stavka, arbitar tuženika odlučit će prihvaća li prijedlog arbitra tužitelja ili predložiti za predsjednika vijeća drugog arbitra. Ako arbitar tuženika u propisanom roku ne postupi sukladno ovoj odredbi, smatra se da je pristao na prijedlog arbitra tužitelja. Ako pak arbitar tuženika postupi sukladno ovoj odredbi, arbitar tužitelja će u daljnjem roku od tri dana od dana zaprimanja prijedloga arbitra tuženika odlučiti pristaje li na prijedlog arbitra tuženika ili će prepustiti odluku o imenovanju predsjednika vijeća predsjedniku Arbitražnog suda. Ako arbitar tužitelja prepusti odluku o imenovanju predsjednika vijeća predsjedniku Arbitražnog suda, za predsjednika vijeća može biti imenovan samo arbitar kojega nije predložio niti arbitar tužitelja niti arbitar tuženika. Ako arbitar tužitelja nije postupio sukladno ovoj odredbi, arbitar tuženika bira predsjednika vijeća u roku od tri dana od dana u kojem je obaviješten da arbitar tužitelja nije postupio sukladno stavku 3. ovog članka. Ako se arbitar tužitelja i arbitar tuženika propuste usuglasiti oko predsjednika vijeća sukladno odredbama ovog članka, predsjednika vijeća odredit će predsjednik Arbitražnog suda. Ako se arbitri u roku od 8 dana ne mogu 
dogovoriti, predsjednika vijeća određuje predsjednik Arbitražnog suda ili njegov zamjenik, s time da se za predsjednika vijeća ne može odrediti arbitar predložen u ranijem postupku dogovornog određivanja. Ako je jedan arbitar predložio predsjednika vijeća, a drugi arbitar se o tom prijedlogu u roku od 8 dana od dana dostave nije očitovao ili nije predložio drugog predsjednika vijeća, smatrat će se da je suglasan s prijedlogom.

Također, ovom odredbom Pravilnika o radu Arbitražnog suda HNS-a sada je propisan i način izbora arbitara (za razliku od prije kada to nije bilo propisano) u postupcimau kojima klub temeljem odredbi Pravilnika o statusu igračai registracijama HNS-a podnese tužbu radi utvrđenja da je ugovor raskinut bez opravdanog razloga ili ako stranke postignu pisani dogovor o tome, a u kojim slučajevima onda postupak vodi i donosi odluke arbitar pojedinac. U ovim postupcima stranke imaju rok od 5 dana za postizanje dogovora o određivanju arbitra pojedinca. Ako se stranke ne mogu dogovoriti u ostavljenom roku, arbitra pojedinca određuje predsjednik Arbitražnog suda ili njegov zamjenik.

Arbitri prije postupka u svakom predmetu trebaju dati pisanu izjavu da pristaju obnašati dužnost arbitra. Arbitri međusobno i s administracijom Arbitražnog suda komuniciraju putem elektronske pošte. Sva očitovanja i izjave volje koje su arbitri i, kasnije, članovi vijeća, dali tim putem, uzimaju se kao valjana i vjerodostojna.

Ova odredba članka 7. Pravilnika o radu Arbitražnog suda HNS-a sada je u suglasju sa člankom 10. Zakona o arbitraži kojom je odredbom propisan i reguliran način imenovanja arbitara. ${ }^{29}$

\section{Administracija}

Administrativne i tehničke poslove za Arbitražni sud obavlja Ured HNS-a. S obzirom na činjenicu da Ured HNS-a nije propisao nikakve posebne pravilnike o vođenju istoga, u praksi Ured HNS-a vodi administrator (tajnik) Arbitražnog suda HNS-a.

\section{Odgovornost}

Osim u slučaju ozbiljnog nedoličnog ponašanja, članovi Arbitražnog suda i njegove administracije neće se smatrati osobno odgovornima za svoje postupke i propuste u vezi s postupcima (članak 50. Pravilnika o radu Arbitražnog suda HNS-a). Smtramo da ova odredba nije dobra i da kao takva ne bi trebala biti u Pravilniku o radu Arbitražnog suda HNS-a. Istina jest da svaka arbitražna ustanova

29 Upravo je ova odredba u "starom" Poslovniku o radu Arbitražnog suda HNS-a rezultirala činjenicom da je pred Županijskim sudom u Zagrebu te Vrhovnom sudu RH u Zagrebu poništen velik broj pravorijeka Arbitražnog suda HNS-a jer je prije sadržavala odredbu po kojoj je arbitre predlagao Izvršni odbor Hrvatskog nogometnog saveza a ne stranke, što je razlog za poništaj pravorijeka sukladno članku 36. stavak 2. točka 1e Zakona o arbitraži. 
pa tako i Arbitražni sud HNS-a uređuje svoja pravila. Ovo sve posebno iz razloga što ograničiti odgovornost članova Arbitražnog suda HNS-a samo na slučaj "ozbiljnog nedoličnog ponašanja" nije dobro jer po tome ispada da članovi Arbitražnog suda ne mogu odgovarati za svoje postupke i propuste, što se u praksi može uvijek dogoditi.

\section{Lista arbitara}

Na internetskim stranicama Hrvatskog nogometnog saveza može se pronaći lista arbitara Arbitražnog suda HNS-a. ${ }^{30}$ Ova lista mijenja se svake četiri godini uz napomenu da se može izmijeniti i ranije ako arbitar prestane obavljati svoju dužnost.

Predsjednik Arbitražnog suda HNS-a jest Ivica Veselić, sudac Županijskog suda u Zagrebu, zamjenik predsjednika Arbitražnog suda HNS-a je Nika Grospić Ivasović, sudac Županijskog suda u Zagrebu, a ostali članovi s liste redom su odvjetnici te 1 (jedan) sveučilišni profesor pravnih znanosti.

U pogledu liste arbitara Arbitražnog suda HNS-a možemo reći da sadrži i pozitivnu i negativnu karakteristiku. Pozitivna karakteristika očituje se u tome da lista arbitara predstavlja jamstvo strankama da su arbitri specijalistički i pravno kvalificirani za donošenje odluka u arbitražnom postupku koji pretpostavlja poznavanje materije sportskog nogometnog prava. S druge strane, negativna karakteristika očituje se u sužavanju autonomije stranaka pri izboru arbitražnog suca.

\section{Neobavljanje dužnosti arbitra i imenovanje zamjenika arbitra}

Ako arbitar ne može, ili više ne želi, obavljati svoju dužnost, njegovo članstvo u vijeću u pojedinom postupku prestaje ako se povuče s te dužnosti ili ako se o tome suglase stranke u postupku. Izvršni odbor HNS-a potvrđuje povlačenje s dužnosti arbitra ako se ono odnosi na cjelokupan rad u Arbitražnom sudu, te na prijedlog predsjednika Arbitražnog suda razrješuje dužnosti arbitra koji se nije sam povukao, a utvrdilo se da više ne može ili ne želi obavljati dužnost.

Predsjedniku, zamjeniku predsjednika ili arbitru Arbitražnog suda dužnost na temelju odluke Izvršnog odbora HNS-a prestaje i kada nastupi razlog koji predstavlja smetnju za izbor, kada izgubi poslovnu sposobnost, hrvatsko državljanstvo i, u drugim slučajevima, kada postoje smetnje za obavljanje dužnosti u Arbitražnom sudu (članak 8. Pravilnika o radu Arbitražnog suda HNS-a). suda.

30 Vidi detaljnije o tome na http://www.hns-cff.hr/propisi i dokumenti HNS-a/arbitri Arbitražnog 


\section{Izuzeće}

Arbitri nisu zastupnici stranaka koje su ih postavile, već moraju biti nepristrani. Zbog toga je arbitar dužan izuzeti se kada postoje razlozi koji se odnose na izuzeće, a i stranke iz tih razloga mogu tražiti izuzeće arbitra. ${ }^{31}$

Član vijeća ili arbitar pojedinac koji odlučuju u sporu ne može biti član Arbitražnog suda ako je sam stranka u sporu ili zastupnik stranke, u radnom odnosu u klubu ili savezu koji je u sporu, ako je sudjelovao u donošenju odluke koja je predmet spora, ako je u krvnom ili tazbinskom srodstvu s nekom od stranaka u sporu, te ako postoje druge okolnosti koje dovode u sumnju njegovu nepristranost. Ako postoje neki od gore citiranih razloga, član Arbitražnog suda HNS-a dužan je o tome bez odgađanja obavijestiti predsjednika vijeća, a ukoliko se radi o predsjedniku vijeća ili arbitru pojedincu, predsjednika Arbitražnog suda. Izuzeće člana vijeća koje odlučuje u sporu ili arbitra pojedinca mogu zatražiti i stranke. Ako se član vijeća ili arbitar pojedinac čije se izuzeće traži sam ne povuče, o zahtjevu za izuzećem odlučit će predsjednik Arbitražnog suda rješenjem. Ako se traži izuzeće predsjednika Arbitražnog suda, o izuzeću će odlučiti zamjenik predsjednika Arbitražnog suda. Stranka može zatražiti izuzeće člana vijeća ili arbitra pojedinca u roku od sedam dana od dana kada je obaviještena o sastavu vijeća ili o imenovanju arbitra pojedinca, odnosno od dana kada je saznala za neku od okolnosti za izuzeće (članak 9. Pravilnika o radu Arbitražnog suda HNS-a).

Ova odredba također je u skladu s odredbama članka 12. Zakona o arbitraži koje se odnose na izuzeće arbitara. Razlika u pristupu instituta izuzeća po Zakonu o arbitraži i starog Zakona o parničnom postupku (koji je bio na snazi prije stupanja na snagu Zakona o arbitraži) sastoji se u proširenju koncepta izuzeća i na one situacije u kojima se ne radi o sumnji u arbitrovu objektivnost, već i o sumnji u njegove sposobnosti da kvalitetno i učinkovito provede arbitražni postupak. ${ }^{32}$

\section{Ispitivanje nadležnosti}

Arbitražni sud može odlučivati o svojoj nadležnosti. Ako se Arbitražni sud smatra stvarno nenadležnim, o tome će donijeti rješenje i obavijestiti predlagatelja. Prigovor na nadležnost Arbitražnog suda može dati i protustranka, ali najkasnije do predaje odgovora na zahtjev u kojemu se upustila u raspravljanje o biti spora (članak 10. Pravilnika o radu Arbitražnog suda HNS-a). Ovdje možemo nadodati i to da se na pitanja nadležnosti u arbitražnom postupku na odgovarajući način analogno primjenjuju i odredbe Zakona o parničnom postupku. Upravo zbog toga ukazujemo na činjenicu da u praksi imamo velik broj slučajeva kojima se Arbitražni

31 Živanović, Aleksandar, Bužanin, Obren, Modul 3, Alternativno rješavanje sporova - Medijacija i arbitraža, Početna obuka - treća godina, Priručnik za stručne saradnike u sudovima, Sarajevo, 2009., str. 78.

32 O izvorima takvog pristupa vidi kritički u Goldštajn, Aleksandar, Triva, Siniša, Međunarodna trgovačka arbitraža, Informator, Zagreb 1987., str. 507. 
sud HNS-a oglasio apsolutno nenadležnim pa je stoga ukinuo sve provedene radnje i odbacio tužbu. ${ }^{33}$

\section{Sjedište}

Potrebno je za istaknuti da se pod sjedištem arbitraže u smislu donošenja odluke podrazumijeva sjedište arbitražnog vijeća u konkretnom sporu u kojem se vodi arbitražni postupak, za razliku od sjedišta arbitraže u širem smislu pod kojim se podrazumijeva mjesto stalnih organa institucionalnih arbitraža. ${ }^{34}$

Stalno sjedište Arbitražnog suda je u Zagrebu, Ulica grada Vukovara 269a. Arbitražni sud u svom radu koristi pečat HNS-a s brojčanom oznakom 8 i nazivom "Arbitražni sud" na donjem obodu pečata (članak 11. Pravilnika o radu Arbitražnog suda HNS-a).

\section{Mjesto vođenja postupka}

Mjesto odlučivanja usmene glavne rasprave pred arbitražom u pravilu je sjedište arbitraže, ali dopušta se mogućnost održavanja rasprave i na drugom mjestu ako je to svrsishodno i ako to zatraže stranke ili arbitri. Kada se govori o sjedištu arbitraže, misli se na mjesto gdje arbitri trebaju donijeti odluku. ${ }^{35}$

Arbitražni postupak vodi se u sjedištu Arbitražnog suda HNS-a. Mjesto arbitraže tradicionalno se određuje kao mjesto u kojem se nalazi sjedište arbitražnog suda, što ne mora značiti da se arbitražni postupak i fizički odvija u tom mjestu. ${ }^{36} \mathrm{Zbog}$ racionalnosti i efikasnosti postupka Arbitražni sud može pojedine radnje (izvođenje dokaza, održavanje rasprave...) izvoditi u bilo kojem mjestu koje smatra prikladnim. Arbitražni sud dužan je o mjestu i vremenu održavanja ročišta ili izvođenja pojedinih dokaza pravodobno obavijestiti stranke (članak 12. Pravilnika o radu Arbitražnog suda HNS-a).

\section{Jezik i pismo postupka}

Arbitražni postupak provodi se na hrvatskom jeziku, a svi podnesci i druga pismena trebaju biti sastavljeni latiničnim pismom na hrvatskom jeziku. Ako je jedna od stranaka stranac, može tijekom postupka na vlastiti trošak koristiti tumača prilikom usmene rasprave i usmeno prevođenje isprava koje se koriste u svrhu dokazivanja (članak 13. Pravilnika o radu Arbitražnog suda HNS-a).

33 O proglašavanju apsolutne nenadležnosti Arbitražnog suda HNS-a vidi u primjeru u nastavku ovog rada pod točkom 6.3.4.

34 Vidi Sesar, Milijan, Praktikum arbitražnog prava, Pravni fakultet u Splitu, 2011., str. 10.

35 Tako Sesar, Milijan, op. cit. str. 10.

36 Više o tome Sikirić, Hrvoje, "Izbor mjesta arbitraže", Pravo u gospodarstvu, vol. 35., 1996., broj 3-4, str. 319 . 
Stranke su dužne sudu upućivati svoje podneske na hrvatskom jeziku. To se odnosi i na punomoć za zastupanje. U slučaju da je isprava sastavljena na stranom jeziku, sudski tumač mora je prevesti na hrvatski jezik, jer u protivnom sud tu ispravu ne može smatrati dokazom. ${ }^{37}$ Pitanje jezika arbitraže može biti važno radi ostvarenja načela procesne ravnoteže saslušanja stranaka i pružanja jednake mogućnosti strankama da sudjeluju u postupku i predstave svoj slučaj arbitražnom sudu. Pružanje mogućnosti strankama da se u arbitražnom postupku služe jezikom koji neće favorizirati niti jednu stranku, smatra se jednom od važnih prednosti arbitraže u odnosu na postupak pred državnim sudom. ${ }^{38}$

\section{Privremene mjere}

Na zahtjev bilo koje stranke ili po službenoj dužnosti Arbitražni sud može odrediti privremenu mjeru koju smatra potrebnom s obzirom na predmet spora (članak 14. Pravilnika o radu Arbitražnog sud HNS-a). No ovdje valja spomenuti da se i sukladno Zakonu o arbitraži svaka stranka, a što podrazumijeva bilo kojeg sudionika nogometnog sporta (npr. igrač ili klub), može obratiti sudu radi određivanja privremenih mjera osiguranja tražbine. Zahtjev jedne od stranaka upućen sudu prije ili u tijeku arbitraže za određivanje privremenih mjera osiguranja tražbine i određivanja takvih mjera nije u nesuglasju s ugovorom o arbitraži (članak 44. Zakona o arbitraži). ${ }^{39} \mathrm{U}$ arbitražnom postupku stranka može zatražiti određivanje privremene mjere osiguranja tražbine i takav zahtjev nije u nesuglasju s ugovorom o arbitraži.$^{40}$

Arbitražni sud HNS-a u svojoj je dugogodišnjoj praksi donio tek nekoliko privremenih mjera. Razlog ovome leži u činjenici što arbitražni postupci u velikoj većini slučajeva traju samo nekoliko mjeseci, nakon čega se vjerovnici brzo naplate putem disciplinskog postupka pri čemu su prijedlozi o donošenju privremene mjere radi osiguranja novčane tražbine bespotrebni jer, kako smo naveli, vjerovnici vrlo brzo dođu do svog novca i to baš preko disciplinskog postupka koji se provodi pred Disciplinskom komisijom HNS-a.

\section{Troškovi}

Tužitelj je obvezan platiti pristojbu za pokretanje postupka pred Arbitražnim sudom. Visinu pristojbe određuje Izvršni odbor HNS-a. Ako tužitelj ne plati pristojbu

37 Tako u odluci VTSRH, Pž 5560/03 od 27. IX. 2005. - Zbirka odluka VTSRH broj 11/93.

38 Triva, Siniša, Uzelac, Alan, op. cit. str. 172.

39 O drukčijim mišljenjima o učinku privremenih mjera u režimu Zakona o izvršnom postupku iz 1978. vidi Triva, Siniša, Belajec, Velimir, Dika, Mihajlo, Sudsko izvršno pravo, 2. izdanje, Zagreb, Informator, 1984., str. 299-392.

40 Detaljnije Sesar, Milijan, "Privremene mjere i mjere radi osiguranja u arbitražnom postupku", Hrvatska pravna revija, Zagreb, 2003., br. 3, str. 109-115. te Sesar, Milijan, "Privremena mjera državnog suda kao intervencija u arbitražni postupak", Hrvatska pravna revija, Zagreb, 2003, br. 5, str. 1-9. 
prilikom podnošenja zahtjeva, sud će ga pozvati da je plati u daljnjem roku od 15 dana pod prijetnjom odbačaja zahtjeva. Ukoliko tužitelj u cijelosti ili djelomično uspije sa svojim zahtjevom, trošak postupka (vještačenje, zastupanje odvjetnika, pristojba i sl.) u cijelosti ili u odgovarajućem dijelu bit će mu dužan naknaditi tuženik (članak 15. Pravilnika o radu Arbitražnog suda HNS-a). Odlukom Izvršnog odbora HNS-a o plaćanju pristojbi od 14. srpnja 2006., koja je dopunjena 30. lipnja 2009. godine, propisano je da kada je podnositelj zahtjeva (tužbe) nogometni klub, tada arbitražna pristojba iznosi 6000,00 kuna, a kada je podnositelj zahtjeva (tužbe) igrač ili trener, da tada arbitražna pristojba iznosi 3600,00 kuna. ${ }^{41}$

Troškovi arbitražnog postupka obuhvaćaju nagradu članovima arbitražnog suda, putne i ostale izdatke arbitra, troškove vještačenja i svjedočenja, zastupanja i pomoći stranci koja je dobila spor, nagrade i troškove ovlaštenika za imenovanje. Kada se govori o arbitražnim troškovima, onda je među autorima prijeporno uglavnom to što ulazi u arbitražne troškove, te na koji se način to određuje. ${ }^{42}$

\section{Stranke pred Arbitražnim sudom HNS-a}

Stranke u postupku mogu biti klubovi HNS-a, igrači koji su registrirani za klub HNS-a, treneri koji imaju ugovor o treniranju s klubom HNS-a, posrednici za transfer igrača kojima je licencu izdao HNS i koji imaju ugovor o zastupanju s klubom HNS-a ili s igračem HNS-a i županijski nogometni savez (članak 16. Pravilnika o radu Arbitražnog suda HNS-a). Strankama se jamče osnovna postupovna prava, a naročito pravo jednakog položaja i pravo na saslušanje. To podrazumijeva posebno pravo da se objasni nečije djelo, podnesu dokazi i sudjeluje u izvođenju dokaza i dobije obrazložena odluka (članak 17. Pravilnika o radu Arbitražnog suda HNS-a). Stranke mogu imenovati zastupnika po svom izboru, među gore navedenim osobama. Stranku, osim zakonskih zastupnika, mogu zastupati odvjetnik, bračni drug, krvni srodnici u izravnoj liniji i član tijela kluba koji je stranka u postupku i koji ima punomoć za zastupanje (članak 18. Pravilnika o radu Arbitražnog suda HNS-a). ${ }^{43}$

Stranke koje su zaključile ugovor istovremeno su i ugovorne stranke i parnične stranke, odnosno protivnici u arbitražnom postupku. Ugovor o arbitraži mora se odnositi na spor koji proizlazi iz određenog pravnog odnosa, koji mora postojati u vrijeme sklapanja ugovora o arbitraži i iz kojeg može nastati jedan ili više sporova. ${ }^{44}$ Osoba koja ima pravni interes da jedna od stranaka uspije u sporu, može joj se

41 Vidi odluke Izvršnog odbora HNS-a od 14. VII. 2006. i 30. VI. 2009.

42 O tome podrobnije Sesar, Milijan, "Troškovi o arbitražnom postupku", Zbornik radova Pravnog fakulteta u Splitu, 1998., 1-2 (49-50), str. 197-209.

43 Svaka stranka u postupku pred Arbitražnim sudom HNS-a može svom zakonskom zastupniku ili punomoćniku dati pisanu punomoć za zastupanje u arbitražnom postupku ili ga pak mogu i usmeno opunomoćiti na raspravi, nakon čega Arbitražni sud HNS-a to utvrdi u raspravnom zapisniku svojim posebnim rješenjem.

44 Tako Sikirić, Hrvoje, "Ugovor o arbitraži", Pravo u gospodarstvu, vol. 41, 2002., broj 2, str. 37. 
pridružiti kao umješač. O dopuštenju miješanja odlučuje vijeće zaključkom (članak 19. Pravilnika o radu Arbitražnog suda HNS-a).

Postupci se vode u pisanom obliku i usmenim putem na glavnoj raspravi (članak 20. Pravilnika o radu Arbitražnog suda HNS-a).

\section{Pismena i rokovi}

Pismena se dostavljaju na adresu koje su dale stranke, odnosno na adresu zastupnika stranke. Pismena se dostavljaju na način koji omogućava dokaz o primitku. Dostava se u načelu obavlja preporučenom pošiljkom uz povratnicu, a u hitnim slučajevima pozivi na raspravu ili obavijest o odgodi mogu se upućivati brzojavom ili telefaksom. U slučaju dvije neuspjele dostave na gore opisane načine, to će se pismeno objaviti u Službenom glasniku HNS-a. Treći dan od dana objave smatra se da je pismeno uručeno (članak 21. Pravilnika o radu Arbitražnog suda HNS-a).

Stranke trebaju svoje podneske dostaviti u roku koji je propisan pravilnikom ili koji je odredio Arbitražni sud. Smatra se da su rokovi poštovani kada je otprema obavljena do ponoći na dan roka i to je potvrđeno primitkom u Uredu HNS-a ili poštanskim žigom. Pošiljatelj dokazuje da je poštovao rok. Kao opće pravilo, rokovi koje određuje Arbitražni sud ne mogu biti kraći od deset dana, niti dulji od 30 dana. U hitnim slučajevima, osobito kada se odlučuje o raskidu ugovora između kluba i igrača, rokovi mogu biti skraćeni na 48 sati. U slučajevima kad ovaj Pravilnik ne propisuje posljedice propusta poštovanja roka, njih utvrđuje Arbitražni sud (članak 22. Pravilnika o radu Arbitražnog suda HNS-a).

Obvezni rokovi počinju teći jedan dan nakon što su stranke primile pismeno koje sadrži rokove. Obvezni rokovi koji su propisani ovim Pravilnikom ne mogu se produživati. Neradni dani i državni praznici u mjestu prebivališta primatelja uračunavaju se u rokove. Rok istječe u ponoć posljednjeg dana roka. Ako je posljednji dan roka neradni dan ili državni praznik u mjestu prebivališta primatelja, rok istječe sljedećeg radnog dana (članak 23. Pravilnika o radu Arbitražnog suda HNS-a).

Rokovi koji su ovim Pravilnikom ostavljeni na diskrecijsku ocjenu Arbitražnom sudu mogu se produžiti zbog valjanih razloga ako je prije njihova isteka za to podnesen opravdani zahtjev. Zahtjev za produženje roka može se odobriti samo jednom (članak 24. Pravilnika o radu Arbitražnog suda HNS-a). ${ }^{45}$

45 Ova odredba nije dobra jer u praksi mogu postojati brojni razlozi zbog čega Arbitražni sud HNS-a, kada postoji za to opravdani razlog, može odobriti produženje roka dvaput ili više puta. No imajući u vidu činjenicu da svaki arbitražni postupak, pa tako i postupak pred Arbitražnim sudom HNS-a, treba biti brz i efikasan, to je sigurno ova odredba usmjerena u tom pravcu kako se ne bi nepotrebno odugovlačio arbitražni postupak između stranaka. 


\section{POSTUPAK PRED ARBITRAŽNIM SUDOM HNS-A}

\section{Pokretanje postupka}

Arbitražni postupak osigurava strankama trajnost raspravljanja (sine strepitu forensi), prihvatljiv ambijent i pomirljiv ton raspravljanja, jednostavnost procesnih formi, brzinu i jeftinoću. Arbitri, osobe povjerenja stranaka, u pravilu su i eksperti za područje o kojemu sude. Relativna nevezanost arbitra za određeni sistem prava pruža im mogućnost da nađu pravičnu soluciju. Arbitražno sudovanje manifestira se kao izraz društvene solidarnosti, zajedničkih koncepcija o pravu i pravičnosti, uzajamne lojalnosti i u trenucima razjedinjenosti, spremnosti stranaka da prihvate rješenje koje nužno ne mora predstavljati maksimalno ostvarenje njihovih zahtjeva. ${ }^{46}$

Postupak pred Arbitražnim sudom pokreće se podnošenjem tužbe u pisanom obliku (članak 25. Pravilnika o radu Arbitražnog suda HNS-a).

Arbitražni postupak centralni je stadij instituta arbitraže kao cjeline. Stranke su u postupku pred arbitražom ravnopravne. ${ }^{47}$

U praksi najčešce postupke pred Arbitražnim sudom HNS-a pokreću igrači i to baš radi isplate dugovanih novčanih iznosa. No kako oni nisu pravno kvalificirani u pogledu sastavljanja tužbe, smatramo da bi bilo svrsishodno da Hrvatski nogometni savez putem svojih internetskih stranica napravi i objavi šprancu ove vrste tužbe koja je u biti vrlo jednostavna. Time bi olakšao igračima pokretanje arbitražnog postupka. Naravno, to bi bilo i ekonomičnije igračima jer ne bi u tom slučaju morali angažirati odvjetnike, što im iziskuje i dodatne troškove. ${ }^{48}$

Što se tiče predaje tužbe, možemo reći da se ona može predati Arbitražnom sudu HNS-a putem pošte ili neposredno putem protokola tajništva Arbitražnog suda HNS-a.

\section{Obvezni sastojci tužbe}

Tužba treba sadržavati naročito:

a) imena i adrese stranaka,

b) opis predmeta spora i zahtjev koji se postavlja,

46 Više o tome Triva, Siniša, Belajec Velimir, Dika, Mihajlo, Građansko parnično procesno pravo, Sveučilište u Zagrebu, Zagreb, 1986., str. 690.

47 Detaljnije Sesar, Milijan, "Načelo javnosti u arbitražnom postupku", Zbornik radova Pravnog fakulteta u Splitu, 2000., br. 3-4 (59-60), str. 355-367; te Sikirić, Hrvoje, "Povjerljivost u arbitražnom postupku", 13. Hrvatski dani arbitraže i mirenja, Zagreb, 2005.; Sesar, Milijan, Načelo javnosti u arbitražnom postupku (dopunjen i izmijenjen rad radi promjene zakonskih propisa), Mostariensia, Mostar, 2006., str. 87-102.

48 Kao dokaz koji govori u prilog ovome jesu obrasci Ugovora o profesionalnom igranju, Stipendijskog ugovora o igranju, Ugovora o treniranju, Sporazuma o raskidu ugovora, ali i Sporazuma o odgodi duga prilikom provođenja licenciranja HNS-a. Svi ovi dokumenti objavljeni su na interentskim (web) stranicama Hrvatskog nogometnog saveza u Word-programu tako da bi bilo učinkovito izraditi i objaviti šprancu tužbe Arbitražnom sudu HNS-a i to baš u postupcima radi isplate. 
c) navode o činjenicama na kojima se zasniva tužba,

d) navode o dokazima,

e) određivanje arbitra člana vijeća ili prijedlog da odlučuje arbitar pojedinac.

Tužitelj treba tužbi priložiti sve isprave koje smatra važnima i predložiti izvođenje drugih dokaza. Uz tužbu treba priložiti dokaz o uplati pristojbe te punomoć zastupniku ako ga stranka ima. Tužba se podnosi u dovoljnom broju primjeraka za sve tuženike i članove vijeća. Tužbe koje su nepotpune, koje nisu dostavljene na hrvatskom pismu ili latiničnom pismu, nepotpisane ili potpisane od neopunomoćenog zastupnika, vraćaju se njihovu pošiljatelju. Arbitražni sud će odrediti kratak rok u kojem se treba dopuniti ili ispraviti tužbe, a u slučaju propusta tužba će se odbaciti rješenjem (članak 26. Pravilnika o radu Arbitražnog suda HNS-a).

\section{Odgovor na tužbu}

Arbitražni cee sud dostaviti tuženiku zaprimljenu tužbu i pozvati tuženika da podnese pisani odgovor u roku od 8 dana od dana dostave poziva, odnosno najkasnije do dana održavanja rasprave, ako je njeno održavanje određeno. U pisanom odgovoru treba se navesti i arbitar kojega se određuje za člana vijeća, odnosno prijedlog da odlučuje sudac pojedinac. Odgovor tuženika s dostavljenim prilozima daje se na uvid tužitelju. Ako tuženik u određenom roku ne podnese pisani odgovor na tužbu ili ne sudjeluje u postupku (ne pristupi na ročište za glavnu raspravu ili na drugi način odbije sudjelovati u postupku), Arbitražni sud nastavit ce postupak i pravorijek donijeti na temelju raspoloživih dokaza. U takvom slučaju, pravorijek o tužbenom zahtjevu može donijeti arbitar pojedinac kojega odredi predsjednik Arbitražnog suda. Stranke u postupku dužne su predočiti Arbitražnom sudu sve raspoložive dokaze bez odugovlačenja. Dokazna sredstva dostavljena sa zakašnjenjem bez opravdanog razloga Arbitražni sud neće uzimati u razmatranje (članak 27. Pravilnika o radu Arbitražnog suda HNS-a).

\section{Protutužba i spajanje postupaka}

Protutužba predstavlja samostalni zahtjev koji tuženik podnosi u istom arbitražnom postupku i o tom zahtjevu sud odlučuje arbitražnom odlukom. Kao u većini pravnih sustava, tako i u arbitražnom postupku pred Arbitražnim sudom HNS-a dopušteno je podnošenje protutužbe. Za to se traže dva uvjeta i to da je predmet protutužbe obuvaćen arbitražnim sporazumom, te da se radi o istom pravnom odnosu. Ovdje je potrebito također istaknuti da podnošenje protutužbe ne znači negiranje tužbe, nego je to samostalni zahtjev koji se iznosi pred arbitražni sud. ${ }^{49}$

49 Sesar, Milijan, op. cit. str. 14. 
U postupcima pred Arbitražnim sudom HNS-a tuženik može sve do zaključenja raspravljanja podnijeti protutužbu ili istaći prigovor radi prebijanja. Predsjednik vijeća odredit će zaključkom da se raspravljanje i odlučivanje o ovim zahtjevima spoji (članak 28. Pravilnika o radu Arbitražnog suda HNS-a).

\section{Izmjene i dopune tužbe}

Tijekom postupka pred Arbitražnim sudom tužitelj može izmijeniti ili dopuniti svoju tužbu, osim kad Arbitražni sud smatra da nije svrsishodno dopustiti takve promjene s obzirom na odugovlačenje koje bi se time prouzročilo ili na štetu koju bi zbog toga mogla pretrpjeti druga strana, ili s obzirom na druge okolnosti (članak 29. Pravilnika o radu Arbitražnog suda HNS-a).

\section{Daljnji podnesci}

Arbitražni sud odlučuje koje daljnje podneske treba zatražiti od stranaka odnosno koje podneske stranke mogu podnijeti i utvrđuje rok za njihovo podnošenje (članak 30. Pravilnika o radu Arbitražnog suda HNS-a). Otvoreno pravosuđenje jest načelo po kojem je sud dužan tijekom postupka omogužiti stranakama da raspravljaju i o njegovim stavovima o procesnom materijalu na kojem će utemeljiti svoju odluku, osobito o pravnoj normi koju će primijeniti. ${ }^{50}$

Strankama se omogućava raspravljanje pred (arbitražnim) sudom tako što ih se obavještava o pismenima suda i podnescima protivnika. Pravila o dostavljanju pismena izraz su načela saslušanja stranaka. ${ }^{51}$

\section{Odlučivanje bez održavanja glavne rasprave}

Kad nakon primitka odgovora tužitelja Arbitražni sud utvrdi da među strankama nije sporno činjenično stanje i da ne postoje druge smetnje za donošenje pravorijeka, može bez održavanja ročišta za glavnu raspravu donijeti pravorijek. Ako to zatraži jedna od stranaka u bilo kojoj fazi postupka, Arbitražni sud dužan je održati ročište za glavnu raspravu radi saslušanja svjedoka, vještaka ili stranaka. Ako takvog zahtjeva nema, vijeće, odnosno sudac pojedinac, odlučuju hoće li održati takvo ročište ili će se odluka donijeti na temelju isprava i druge raspoložive procesne građe (članak 31. Pravilnika o radu Arbitražnog suda HNS-a).

50 Više o tome Triva, Siniša, "Esej o otvorenom pravosuđenju", Godišnjak Pravnog fakulteta u Sarajevu, Spomenica S. Jakšiću i S. Kamhiju, sv. XXI, Sarajevo 1973., str. 343-364. - Napomena: Esej je objavljen, prilagođen odredbama novog Zakona o parničnom postupku od 24. XII. 1976., kao prilog (§ 46) u knjizi Novo parnično procesno pravo, str. 209-226, autora Triva, Siniša, Belajec, Velimir, Dika, Mihajlo, Informator, Zagreb, 1977.

51 Tako Grbin, Ivo, Zakon o parničnom postupku, Organizator, Zagreb, 2000., str. 100. 


\section{Dokazi}

Izvođenje dokaza i prikupljanje ostale procesne građe provodi arbitražno vijeće, odnosno arbitar pojedinac. Teret dokaza je na strankama. Izuzetno, sud može i sam odrediti izvođenje pojedinih dokaza ako smatra da su ti dokazi bitni za donošenje pravilnog pravorijeka o predmetu spora. Ako neka od stranka ne dostavi dokaz u roku koji joj je ostavio Arbitražni sud, odlučit će se temeljem ostalih dokaza (članak 32. Pravilnika o radu Arbitražnog suda HNS-a).

\section{Izvođenje i ocjenjivanje dokaza}

Dokazivanje obuhvaća sve činjenice važne za donošenje pravorijeka.

Arbitražni sud može izvesti sljedeće dokaze:

a) saslušanje stranaka;

b) saslušanje svjedoka;

c) ocjenjivanje nalaza i mišljenja vještaka i po potrebi njihovo saslušanje;

d) ocjenjivanje dostavljenih ili pribavljenih isprava;

e) sve druge dokaze koje smatra relevantnima.

Arbitražni sud ocjenjuje dokaze po svom uvjerenju temeljem savjesne i brižljive ocjene svakog dokaza zasebno i svih dokaza zajedno. Arbitražni sud može odbiti izvođenje dokaza koje je predložila stranka, a koje ne smatra relevantnima, koji nemaju veze s utvrđenim činjenicama ili koji bi inače doveli do nepotrebnog odugovlačenja postupka. Ako stranka predloži izvođenje dokaza koji bi izazvao troškove, dužna je po nalogu Arbitražnog suda unaprijed položiti iznos potreban za podmirenje tih troškova. Kad izvođenje dokaza predlože obje stranke ili kad ga Arbitražni sud odredi po službenoj dužnosti, Arbitražni sud će odrediti da iznos potreban za podmirenje troškova polože obje stranke na jednake dijelove. Ako je izvođenje dokaza odredio Arbitražni sud, može se odrediti, ovisno o okolnostima, da samo jedna stranka položi iznos potreban za podmirenje troškova. Arbitražni sud može naložiti svakoj osobi koja je subjekt Statuta i pravilnika HNS-a da dostavi relevantne dokaze koje ima u svom posjedu te da svjedoči u postupku (članak 33. Pravilnika o radu Arbitražnog suda HNS-a).

\section{Saslušanje svjedoka}

Predsjednik vijeća, odnosno arbitar pojedinac, utvrđuje identitet svjedoka i upozorava ga na posljedice lažnog svjedočenja te provodi njegovo saslušanje. Stranke imaju mogućnost postavljanja pitanja svjedocima (članak 34. Pravilnika o radu Arbitražnog suda HNS-a). 


\section{Vještačenje}

Kada je potrebno znanje određene struke da bi se utvrdile ili ocijenile određene činjenice, Arbitražni sud može odrediti vještačenje.

Vještak će napraviti izvješće u roku koji utvrdi Arbitražni sud. Vještak može dati iskaz na raspravi. Arbitražni sud po službenoj dužnosti ili na zahtjev jedne od stranaka može:

a) zahtijevati dodatne informacije od vještaka;

b) zatražiti novo mišljenje od drugog vještaka, ako je prvo izvješće nepotpuno, nerazumljivo ili kontradiktorno.

Odredbe o izuzeću analogno se primjenjuju i na vještake (članak 35. Pravilnika o radu Arbitražnog suda HNS-a).

\section{Obveza surađivanja s Arbitražnim sudom HNS-a}

Svaka osoba koja je subjekt Statuta i pravilnika saveza obvezna je odgovoriti na pozive Arbitražnog suda, bez obzira na osnove. Stranke i njihovi zastupnici mogu predložiti odgodu zakazanog ročišta samo iznimno i iz opravdanih razloga. O prijedlogu za odgodu odlučuje predsjednik vijeća. Ako procijeni da se prijedlog daje iz neopravdanih razloga i s ciljem odugovlačenja postupka, odbit će prijedlog za odgodom ročišta. U slučaju nesuradnje s Arbitražnim sudom, osim ako se ne radi o strankama, predsjednik vijeća ili arbitar pojedinac mogu zatražiti od Disciplinske komisije HNS-a da suspendira osobu koja se ne odaziva pozivima i podnijeti disciplinsku prijavu zbog zanemarivanja obveza (članak 36. Pravilnika o radu Arbitražnog suda HNS-a).

\section{Zapisnik}

Ako se održava glavna rasprava, predsjednik vijeća, odnosno arbitar pojedinac, imenuju osobu koja vodi zapisnik, a zapisnik nakon završetka ročišta potpisuju arbitri i stranke (članak 37. Pravilnika o radu Arbitražnog suda HNS-a). Zapisnik potpisuju svi sudionici glavne rasprave, uz napomenu da potpisani primjerak ostaje u spisu predmeta Predsjednika arbitražnog vijeća, a nepotpisani primjerak zapisnika uručuje se strankama.

\section{Zaključenje glavne rasprave}

Kada se izvedu dokazi, predsjednik vijeća, odnosno arbitar pojedinac, objavljuje zaključenje glavne rasprave. Od tog trenutka stranke ne mogu predlagati nikakve nove činjenice ili dokaze (članak 38. Pravilnika o radu Arbitražnog suda HNS-a). 
Ovdje možemo spomenuti i to da se u praksi prilikom rješavanja arbitražnih sporova pred Arbitražnim sudom HNS-a znalo u nekoliko navrata dogoditi da bi se glavne rasprave nakon njihova zaključenja ponovno otvarale. Razlozi tome leže u činjenici što se to događalo u dugotrajnim višegodišnjim arbitražnim postupcima (prilikom kojih se izmijenilo i arbitražno vijeće) gdje se ne bi svi dokazi izveli od ranijeg arbitražnog vijeća koje su stranke tijekom trajanja postupka predložile, a sve s rezultatom potpunijeg utvrđivanja činjenica i naposljetku donošenja što kvalitetnije odluke.

\section{ODLUČIVANJE ARBITRAŽNOG SUDA HNS-A}

\section{Način odlučivanja}

Kad arbitražni sud nađe da je predmet raspravljen tako da se može donijeti odluka, zaključit će raspravu i donijeti arbitražni pravorijek. Pravorijek je pravomoćna, konačna i za stranke obvezujuća odluka o predmetu spora, izjednačen s pravomoćnom presudom redovnog suda, jer se ne može pobijati redovnim pravnim lijekom ni pred arbitražom višeg stupnja ni pred redovnim sudom. ${ }^{52}$

Općenito je prihvaćeno načelo da se odluke donose većinom glasova..$^{53}$

Arbitražni sud donosi pravorijek običnom većinom članova vijeća. Prilikom odlučivanja od strane 3 (tri) člana arbitražnog vijeća, svi nazočni obvezni su glasovati. U slučajevima kada bi se donosili pravorijeci bez održavanja glavne rasprave (uz prethodno ispunjene uvjete za to), odluka se može donijeti i putem pisanog izjašnjavanja članova vijeća, na prijedlog predsjednika vijeća. O pitanjima vođenja postupka predsjednik vijeća može sam odlučivati izvan sjednice vijeća. Arbitražni sud tijekom vijećanja i glasovanja može odučiti da se rasprava ponovno otvori ako je to potrebno radi dopune postupka ili razjašnjenja pojedinih važnijih pitanja. U slučaju da postupak vodi arbitar pojedinac, sve radnje iz ovog članka obavlja samostalno (članak 39. Pravilnika o radu Arbitražnog suda HNS-a).

Ovdje ukazujemo na iznimku, a to je kada se arbitražni postupak vodi pod predsjedanjem predsjednika vijeća kao suca pojedinca, čemu prethodi zajednički dogovor odnosno sporazum obje stranke postupka o tome da će postupak voditi jedna osoba - sudac pojedinac.

\section{Vrste odlučivanja}

Arbitražni sud u postupku donosi:

a) pravorijek kojim Arbitražni sud odlučuje o osnovanosti i visini pojedinog tužbenog zahtjeva;

52 Detaljnije o tome kod Dika, Mihajlo, "Marginalije uz problem djelotvornosti arbitražnog pravorijeka", Pravo u gospodarstvu, vol. 45., 2006., broj 2, str. 37-55.

53 Goldštajn, Aleksandar, Triva, Siniša, op. cit. str. 517. 
b) rješenje kojim Arbitražni sud utvrđuje svoju nenadležnost, obustavlja arbitražni postupak, kojim predsjednik Arbitražnog suda odlučuje o izuzeću i promjeni arbitra u vijeću ili arbitra pojedinca, kao i kojim se odlučuje o drugim pitanjima o kojima se ne donosi odluka ili zaključak;

c) zaključak kojim Arbitražni sud odlučuje o postupovnim pitanjima.

Arbitražni sud može donijeti i djelomični pravorijek i međupravorijek. Djelomični pravorijek smatra se samostalnim pravorijekom (članak 40. Pravilnika o radu Arbitražnog suda HNS-a).

\section{Nagodba}

Stranke mogu tijekom postupka spor riješiti nagodbom. Arbitražni sud nije dužan takvu nagodbu obrazložiti. Nagodba se može sklopiti i pred arbitrom pojedincem. Nagodba ima jednaku pravnu snagu i učinak kao i pravorijek (članak 41. Pravilnika o radu Arbitražnog suda HNS-a).

\section{Oblik i sadržaj pravorijeka}

Arbitražni sud pravorijek će donijeti u pisanom obliku, koji sadrži sljedeće:

a) datum kada je pravorijek donesen;

b) poslovni broj pravorijeka;

c) imena članova vijeća, odnosno suca pojedinca;

d) imena i/ili nazive stranaka i svih zastupnika ako ih ima;

e) izreku o prihvaćanju ili odbijanju pojedinih zahtjeva koji se odnose na glavnu stvar i sporedna traženja, uključujući i troškove;

f) provedene dokaze;

g) činjenično stanje i zakonske propise;

h) potpis predsjednika i članova vijeća, odnosno potpis arbitra pojedinca.

Člankom 2. Zakona o arbitraži definira se konačni pravorijek kao "odluka kojom je odlučeno o osnovi i visini pojedinog zahtjeva" i usporedbom ove definicije sa člankom 325. Zakona o parničnom postupku kojim se određuje da se "presudom odlučuje o zahtjevu koji se tiče glavne stvari i sporednih traženja", zaključujemo da je konačni pravorijek donesen u arbitražnom postupku pandan presudi donesenoj u parničnom postupku pred državnim sudovima, s tim što je konačni pravorijek često ujedno i odluka protiv koje nema mjesta žalbi.

U pogledu pravorijeka Arbitražnog suda HNS-a možemo reći da je pravorijek valjan i ako ga koji od članova arbitražnog vijeća odbije potpisati ako je pravorijek potpisala većina članova vijeća, te je na pravorijeku utvrdila to uskraćivanje potpisa. Ukoliko su stranke suglasne, pravorijek se može napisati u nastavku zapisnika s 
ročišta, bez obrazloženja, i u tom slučaju neće se slati pisani otpravak pravorijeka (članak 42. Pravilnika o radu Arbitražnog suda HNS-a).

U skladu s pravnim položajem arbitraže, a posebno s pravnim učincima njene odluke, razumljiv je zahtjev da odluka sadrži sve elemente kao i presuda redovnog suda. Pismena izrada arbitražne presude preduvjet je za kasnije traženje njihova priznanja i izvršenja. Obrazloženje je i kod arbitražne odluke onaj dio pojedinačnog pravnog akta koji daje elemente za ocjenu njegove činjenične i pravne osnovanosti. U procesnom pogledu, svi arbitri moraju potpisati izvornik presude i sve prijepise. U slučaju da neki od arbitara uskrati ovaj potpis, arbitražna presuda važi ako je presudu potpisala većina arbitara na samoj presudi. ${ }^{54}$

O obrazloženju pravorijeka izabranog suda Kandare navodi da su arbitri dužni obrazložiti svoju odluku bez obzira na to odlučuju li o osnovanosti tužbenog zahtjeva primjenom pravila određenog materijalnog prava ili su ih stranke ovlastile da odluče po načelima pravičnosti (ex aequo et bono, comme amiables compositeurs). ${ }^{55}$ Stranke koje su se sporazumjele da arbitražna odluka ne mora biti obrazložena ne mogu tražiti poništaj odluke iz razloga što nije obrazložena. Obrazloženje arbitražne odluke ne mora biti iscrpno, a rezultati zaključivanja o relevantnim činjenicama, a naročito o pravu koje na njih treba primijeniti, ne moraju biti valjani. Međutim, arbitraža mora iznijeti razloge svoje odluke u pogledu svakog zahtjeva o kojem je odlučivala. Ako ne iznese razloge za koji od zahtjeva, onda se smatra da obrazloženje djelomično nedostaje, pa uslijed toga ima mjesta zahtjevu za poništaj takve arbitražne odluke. Poništaju arbitražne odluke nema mjesta ako su arbitri obrazložili svoju odluku, iako prema ugovoru o arbitraži to nisu bili dužni učiniti". ${ }^{56}$

Izvornik pravorijeka Arbitražnog suda HNS-a i sve njegove prijepise potpisuju svi izabrani suci (arbitri)..$^{57}$

\section{Obavijest o pravorijeku}

Nakon što je donio pravorijek, Arbitražni sud će ga u pisanom obliku dostaviti Uredu HNS-a, koji će ga dostaviti strankama ili njihovim zastupnicima. U hitnim slučajevima, osobito ako se odlučivalo o raskidu ugovora između kluba i igrača, Arbitražni sud može obavijestiti stranke samo o pravorijeku, a naknadno, u roku od 30 dana, dostaviti obrazloženje (članak 43. Pravilnika o radu Arbitražnog suda HNS-a).

54 Detaljnije Trifković, Miloš, Međunarodno poslovno pravo, Ekonomski fakultet u Sarajevu, Sarajevo, 2009., str. 567-568.

55 Više Kandare, Boris, Pobijanje arbitražne odluke, Knjižnica Pravnog fakulteta Sveučililšta u Zagrebu, Zagreb, 1986.

56 Kandare, Boris, opt. cit. u bilješci 26, str. 90 i 91.

57 Kandare, Boris, op. cit. u bilješci 26, str. 92, dodatno navodi i da zbog povrede pravila o potpisivanju arbitražne odluke može se podnijeti tužba radi poništaja arbitražne odluke ako odluku nije potpisala većina arbitara ili ako odluka ne sadrži pismenu konstataciju većine arbitara koji su potpisali odluku, da je manjina imenovanih arbitara uskratila potpis. Smatra se da se može s uspjehom zahtijevati poništaj arbitražne odluke na kojoj je jedan arbitar potpisao drugoga, bez obzira na to što je na to bio ovlašten. 
Pravilnik o radu Arbitražnog suda HNS-a, kao ni Zakon o arbitraži, ne predviđa rokove za izradu i pisani otpravak pravorijeka izuzev gore citirane odredbe o obavijesti o pravorijeku. Stoga se drži da bi arbitražni sud trebao donijeti pravorijek, izraditi obrazloženje pravorijeka i otpraviti pisani pravorijek primjerenom brzinom izbjegavajući odugovlačenje postupka. ${ }^{58}$

\section{Okončanje postupka}

Donošenjem konačnog pravorijeka okončava se arbitražni postupak o pitanjima o kojima je odlučeno.

Postupak se može okončati i rješenjem Arbitražnog suda ako:

a) tužitelj povuče tužbu;

b) stranke sporazumno odluče o okončanju postupka;

c) Arbitražni sud utvrdi da je nastavak postupka iz nekog drugog razloga postao nepotreban ili nemogué (članak 44. Pravilnika o radu Arbitražnog suda HNS-a).

\section{Obvezatnost pravorijeka}

Pravorijek Arbitražnog suda konačan je i obvezuje stranke. Nakon isteka roka za ispunjenje obveze koja proizlazi iz pravorijeka Arbitražnog suda, tužitelj može podnijeti disciplinsku prijavu Disciplinskoj komisiji HNS-a i zatražiti pokretanje disciplinskog postupka protiv tuženika zbog neispunjenja obveze (članak 45. Pravilnika o radu Arbitražnog suda HNS-a).

\section{Ispravak i tumačenje pravorijeka}

U roku od 30 dana od dana dostave pravorijeka jedna stranka može:

a) tražiti od Arbitražnog suda da u pravorijek ispravi računsku grešku, grešku u pisanju ili drugu grešku slične naravi;

b) tražiti od Arbitražnog suda da dade tumačenje određenog dijela pravorijeka, osobito o načinu ispunjavanju obveze.

Ako Arbitražni sud smatra da je zahtjev za ispravak greške ili za tumačenjem opravdan, ispravit će pravorijek ili dati tumačenje. Arbitražni sud može i sam, u roku od 30 dana od dana donošenje pravorijeka, ispraviti grešku iz stavka 1. ovog članka (članak 46. Pravilnika o radu Arbitražnog suda HNS-a).

58 Vidi više kod Kaleb, Zorislav, "O donošenju i izradi arbitražnog pravorijeka", Pravo $u$ gospodarstvu, vol. 42., 2003., broj 2, str. 74-82. 


\section{Objava pravorijeka}

Povjerljivost arbitražnog postupka odnosi se na obvezu stranaka i arbitara (i arbitražne ustanove) da ne otkriju ili ne odaju informaciju koja se odnosi na stranke, sadržaj postupka, dokaze i dokumentaciju, zapisnike i na odluke donesene u arbitražnom postupku. Nejavnost arbitražnog postupka i njegova povjerljivost tradicionalno se smatraju glavnim prednostima arbitraže u odnosu na suđenje pred državnim sudovima. Povjerljivost se odnosi na podatke o postojanju arbitraže, dokumente nastale u arbitražnom postupku i one korištene kao dokaz, iskaze svjedoka i vještaka, poslovne tajne, zapisnike iz arbitražnog postupka, odlučivanje arbitara, pravorijek i slično. ${ }^{59}$

Sve pravorijeke od općeg interesa HNS može objaviti u obliku koji odredi Arbitražni sud, s time da se identitet uključenih stranaka ne objavljuje (članak 47. Pravilnika o radu Arbitražnog suda HNS-a). Možemo istaknuti da u svom dosadašnjem radu Arbitražnog suda HNS-a nije zabilježen niti jedan slučaj da je Arbitražni sud HNS-a objavio svoj pravorijek.

Iako Pravilnikom o radu Arbitražnog suda HNS-a nije definirano gdje će se pravorijek objaviti, mišljenja smo da to treba biti u Službenom glasniku HNS-a, a ne putem elektroničkih i drugih medija. Ovo sve posebno iz razloga što je Službeni glasnik HNS-a javno glasilo HNS-a i kao takvo javno je dostupno na web-stranici Hrvatskog nogometnog saveza, a u njemu se objavljuju brojne druge odluke svih pripadnika nogometne organizacije.

Shodno tome, u slučaju objave pravorijeka može svatko, bilo da se radi o djelatniku nogometne organizacije ili o nekom trećem, u bilo kojem trenutku nesmetano izvršiti uvid u svaki pojedini Službeni glasnik HNS-a, pa tako i u objavljeni pravorijek Arbitražnog suda HNS-a.

\section{Pravni lijekovi}

Pravorijek Arbitražnog suda je konačan i protiv njega se ne može uložiti žalba. Iznimno, Arbitražni sud može obnoviti postupak ako nezadovoljna strana u roku od 2 mjeseca od dana dostave pravorijeka predloži nove dokaze i istakne nove činjenice za koje nije znala i nije mogla znati u trenutku donošenja pravorijeka, a koji bi mogli bitno utjecati na donošenje pravilnog pravorijeka o predmetu spora. Rok od dva mjeseca započinje onog dana kada je odluka primljena u cijelosti, zajedno s obrazloženjem. O prijedlogu za obnovu postupka odlučuje vijeće, odnosno sudac pojedinac, koji su donijeli pravorijek u postupku za koji se predlaže obnova (članak 48. Pravilnika o radu Arbitražnog suda HNS-a).

59 Vidi Sikirić, Hrvoje, "Povjerljivost u arbitražnom postupku", Pravo u gospodarstvu, vol. 45., 2006., broj 2, str. 127-161. 


\section{ZAKLJUČAK}

Arbitražni sud HNS-a predstavlja samostalni i stalni jednostupanjski sud koji je osnovao Izvršni odbor Hrvatskog nogometnog saveza prije svega radi rješavanja sportsko-nogometnih statusnih pitanja i imovinsko-pravnih sporova između subjekata Hrvatskog nogometnog saveza.

U pogledu organizacijskih i postupovnih odredbi Pravilnika o radu Arbitražnog suda HNS-a, možemo reći da se ovim radom detaljno analiziraju te odredbe, uz napomenu da smatramo kako postoje određene stvari koje nisu još bolje definirane, a njihovim bi se uređenjem zasigurno pridonijelo još kvalitetnijem i bržem rješavanju arbitražnih sporova pred Arbitražnim sudom HNS-a.

Tako Pravilnik o radu Arbitražnog suda HNS-a ne sadržava obligatoran rok za izradu i otpremu svojih odluka, što u praksi stvara velike probleme jer nakon zaključenja glavne rasprave nema obveznog roka do kada bi se ta odluka morala izraditi i otpremiti arbitražnim strankama kao sudionicima postupka.

Zato smatramo da bi bilo potrebno u Pravilnik o radu Arbitražnog suda HNS-a unijeti novu odredbu koja bi propisivala obvezu Arbitražnog suda HNS-a da se od dana zaključenja glavne rasprave odluka morala izraditi i otpremiti strankama, primjerice, najkasnije u roku od 30 dana, a u iznimnim slučajevima najkasnije u roku od 60 dana.

Osim toga, smatramo da bi bilo dobro da Arbitražni sud HNS-a neke svoje najznačajnije odluke objavljuje u Službenom glasniku HNS-a, kao javnom glasilu Hrvatskog nogometnog saveza, kako bi svim subjektima i sudionicima nogometne organizacije bila što dostupnija praksa toga suda, što će zasigurno doprinijeti jačanju pravne sigurnosti i ujednačavanju sudske prakse Arbitražnog suda HNS-a.

Želimo naglasiti $i$ to da bi bilo svrsishodno i učinkovito pristupiti izmjenama i dopunama Zakona o arbitraži i to baš posebice članka 10., zbog sve većeg broja tzv. sportskih arbitražnih sudova koji jednostavno nemaju vremena čekati protek zakonski određenih rokova za imenovanje arbitara, Za sportske arbitraže isti rokovi trebaju biti kraći. Osobno smatramo da bi zakonski rok od 30 dana trebalo smanjiti na 5 ili 8 dana jer se radi o jednostavnoj normi koja se zasniva samo na imenovanju arbitara stranaka u postupku, a ta odredba odnosila bi se isključivo na sportske arbitražne ustanove. Primjer ovoga možemo navesti upravo u nogometu kao sportu gdje jedan od dva prijelazna roka (točnije zimski prijelazni rok) traje samo 30 dana i u slučaju izjavljivanja raskida ugovora jedne strane, proći će cijeli prijelazni rok dok strane međusobno ne imenuju arbitre u budućem arbitražnom postupku. No ovo pitanje zahtijeva podrobniju i detaljniju analizu, što ćemo ostaviti za budućnost. 


\section{CROATIAN FOOTBALL FEDERATION'S ARBITRATION COURT WITH PARTICULAR REFERENCE TO THE RULEBOOK ON THE WORK OF CFF'S (HNS'S) ARBITRATION COURT}

Over the last twenty or so years, football as a sport has evolved not only on the field, but also 'off' the field'. There are countless examples, but one of the most significant ones in the Republic of Croatia is certainly football arbitration disputes and their resolution. These are football disputes in the case of issues of players, clubs, coaches, as well as issues related to fees for the coaching and development of players and the fees for mechanisms of solidarity among clubs and of the associations belonging to the Croatian Football Federation. Also related to this, are also the property disputes arising between individual subjects of CFF (HNS) e.g. club-club, player-club, coach-club, club-county football federation) which are resolved before the Arbitration Court of the CFF (HNS). The co-authors in this paper explain the way disputes are led and resolved before the CFF (HNS) Court, as well as the organizational and procedural provisions of the Rulebook on the work of the CFF (HNS) Arbitration Court.

Key words: arbitration, dispute, football, sports law, contract 